\title{
AN UNUSUAL COMPLICATION OF JEJUNAL BIOPSY
}

\author{
Major R. N. T. THIN M.B., M.R.C.P.(Edin) R.A.M.C. \\ Military Hospital, Terendak, Malaysia
}

PER-ORAL small intestinal mucosal biopsy using the technique described by Crosby and Kugler in 1957 is established as a valuable procedure. It causes little inconvenience or discomfort to the patient and is used in the investigation of a variety of disorders. Hazards such as perforation, haemorrhage and post-biopsy fever are now rare but recently an unusual complication was encountered.

\section{Case Report}

A 24 year old white soldier was admitted with infective hepatitis. The liver function tests when his jaundice was most marked were: serum bilirubin $4.8 \mathrm{mg}$ per $100 \mathrm{ml}$, alkaline phosphatase 12 King Armstrong units, serum glutamic oxaloacetic transaminase 114 Smith Frankel (SF) units per ml, serum glutamic pyruvic transaminase $160 \mathrm{SF}$ units per ml. A Watson capsule (Holmes et al 1961) was passed in the usual manner. When an antero-posterior radiograph of the abdomen was taken three hours later it showed the capsule in the second loop of the jejunum but with the cap separated from the body. The body was withdrawn when it was found that an adult female Ascaris lumbrocoides 26 centimetres long, had entered the aperture, pushed the cap off the body and become impacted in the capsule as shown in figure 1. After the patient had received 4 grammes of piperazine citrate another adult round worm was passed. Later a satisfactory biopsy specimen was obtained.

\section{Discussion}

Ascariasis is particularly prevalent in the Far East. The adult worm, which lives in

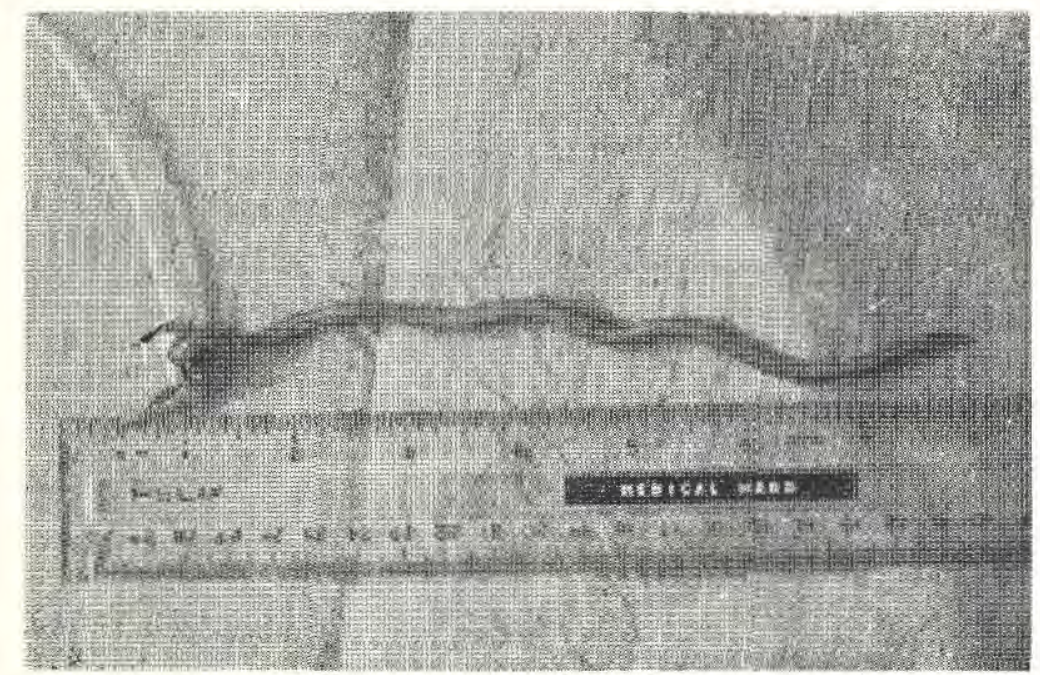

Fig. 1 
the lumen of the small intestine, shows a remarkable tendency to wander, entering ducts, migrating to the stomach and oesphagus and occasionally emerging from the mouth, nose or other orifices. This case is another example of the round worm's 'wanderlust '; there was however no clinical or biochemical evidence of biliary obstruction.

\section{Conclusion}

When Ascaris lumbricoides infestation has been demonstrated or is strongly suspected it is advisable to give a vermifuge before attempting per-oral small intestinal mucosal biopsy.

\section{REFERENCES}

Grosby, W. H. and Kugler, H. W. (1957). Am. J. dig. Dis. 2, 236.

Holmes, R., Houribane, D., O'B. and Booth, C. C. (1961). Lancet 1, 81.

\section{Appointments to The Queen}

Major-General P. R. Wheatley, D.S.O., late R.A.M.C. has been appointed Honorary Surgeon to The Queen, in succession to Major-General R. A. Stephen, C.B., C.B.E., retired.

Brigadier E. H. P. Lassen, D.S.O., M.R.C.S., L.R.C.P., late R.A.M.C is appointed Honorary Physician to the Queen, in succession to Major-General W. B. F. Brennan, C.B., M.B., B.Ch., B.A.O., retired.

\section{Honorary Consultant}

Colonel C. S. Nicol, T.D., M.D., F.R.C.P., late R.A.M.C. (T.A.), has been appointed Honorary Consultant in Venereology to the Army at Home in succession to. Mr. A. J. King, M.B., F.R.C.S., who has retired. 